\title{
Hubungan Antara Body Mass Index (BMI) dan Pengalaman Karies pada Anak Pra-Sekolah di Puskesmas Rawang
}

\author{
Dini Chairani Prima ${ }^{1}$, Murniwati²
}

Korespondensi: Murniwati, murniwati@dent.unand.ac.id, Telp: 08116614415

\begin{abstract}
Background: Food choices and nutritional intake may affect the dental health and body weight. Malnutrition can influence dental caries due to altered saliva composition and impaired secretion. Intake of foods rich in carbohydrates can be risk factor for overweight, obesity and tooth decay. BMI is considered a simple method to analyse a nutritional status. Purpose: The aim of this study is to determine the relationship between BMI and caries status of preschool children in Puskesmas, Rawang District of Padang City. Method: This study used the cross sectional design, with the total sample were 72 students from 6 from Early Childhood Development Place (PAUD) which located in Puskesmas Rawang, and selected through proportionate stratified random sampling method. The analysis of the relationship between BMI (underweight, normal weight, and obese) and caries status is conducted with Kruskal Wallis' Test and followed by Mann-Whitney's Test. Result: Ultimately, this study shows that there are significant differences $(p<0.05)$ between BMI (underweight, normalweight, and obesity) and caries status, which for the category of underweightobesity showed significant difference $(p<0.05)$, whereas in the category of underweight-normalweight and normalweight-obesity showed there is no significant differentiation $(p<0.05)$. The results of this study indicated that the highest score of caries is in the categories of underweight children.Conclusion: As the conclusion of this study revealed that there is a relation between Body Mass Index (BMI) and Caries Status.
\end{abstract}

Keywords: Body Mass Index (BMI), caries

Affiliasi penulis : ${ }^{1}$ Fakultas Kedokteran Gigi, Universitas Andalas

\section{PENDAHULUAN}

Karies gigi merupakan salah satu permasalahan kesehatan gigi yang paling banyak ditemukan di masyarakat. Pada anak-anak karies gigi adalah permasalahan kesehatan gigi yang paling banyak dikeluhkan. ${ }^{1}$ Kesehatan gigi dan mulut yang buruk akan berdampak kepada kualitas hidup anak karena akan berefek kepada beberapa aspek seperti bicara dan pengunyahan..3 Karies gigi juga akan menyebabkan rasa sakit, ketidaknyamanan, susahnya anak tidur pada malam hari dan hal tersebut bisa menyebabkan mereka tidak hadir sekolah. ${ }^{2}$ Pengalaman karies pada masa gigi sulung dianggap akan berpengaruh pada gigi permanen nantinya. ${ }^{4}$

World Health Organization (WHO) pada tahun 2012 menyatakan bahwa 60- 90\% anak-anak sekolah di dunia memiliki karies gigi. ${ }^{5}$ Karies gigi juga dilaporkan menjadi penyakit paling umum dialami anak-anak di Amerika Serikat pada tahun 2011-2012 sekitar 22,7\% anak umur 2-5 tahun mempunyai pengalaman karies. ${ }^{6}$ Prevalensi Early Childhood Caries (ECC) di Eropa Timur ditemukan tinggi hingga $56 \%$ pada tahun $2004 .^{7}$

World Health Organization (WHO) pada tahun 2003 menjelaskan bahwa pada sebagian negaranegara berkembang prevalensi karies gigi tinggi karena lebih dari $90 \%$ karies gigi tidak diobati. Tingkat 
karies lebih tinggi pada gigi sulung daripada gigi permanen pada anak-anak di beberapa negara berkembang seperti negara-negara di Asia dan Afrika. ${ }^{8}$ Prevelensi karies gigi pada anak usia 3-5 tahun di India menurut National Oral Health Survey pada tahun 2004 adalah 51,9\%. ${ }^{9}$ Data dari The Third National Oral Health Survey di China pada tahun 2007 menunjukkan bahwa prevalensi karies pada anak prasekolah yang berusia 5 tahun adalah tinggi yaitu sebesar $66 \% .{ }^{10}$ Anak- anak prasekolah adalah anakanak yang berusia 3-6 tahun. ${ }^{11}$

Menurut laporan penelitian oleh pengendalian dan pencegahan penyakit pada tahun 2007 menunjukkan bahwa karies gigi di Indonesia telah meningkat khususnya pada anak usia balita dan anak prasekolah, yaitu dari $24 \%$ menjadi $28 \%$ dimana pada anak usia 2-5 tahun meningkat $70 \%$ dari karies yang ditemukan. ${ }^{12}$ Riset kesehatan dasar (Riskesdas) 2013 menyebutkan bahwa prevalensi penduduk yang bermasalah dengan kesehatan gigi dan mulutnya pada kelompok umur 1-4 tahun adalah 10,4\%, sedangkan pada kelompok umur 5-9 tahun adalah 28,9\%. Pada Sumatera Utara menurut Riskesdas 2013 persentase penduduk yang bermasalah dengan kesehatan gigi dan mulutnya sebesar 19,4\%, sedangakan di Sumatera Barat persentase penduduk yang bermasalah dengan kesehatan gigi dan mulutnya sebesar 22,2\%. ${ }^{13}$ Prevalensi Karies pada anak TK di kota Padang pada tahun 2009 sebesar $52 \% .{ }^{14}$

Pilihan makanan dan asupan gizi akan berefek kepada kesehatan rongga mulut dan berat badan.15,16 Penelitian Bafti LS di Iran tahun 2009-2010 yang dilakukan pada anak umur 3-6 tahun dengan kriteria eksklusi tidak terdapat gigi permanen, menunjukkan hasil bahwa anak dengan kelebihan berat badan memiliki status karies yang rendah. Anak yang kekurangan berat badan memiliki gizi yang buruk dan akan mempengaruhi tingkat karies karena akan berefek kepada sekresi dan komposisi saliva. ${ }^{17} \mathrm{Di}$ Jawa Tengah penelitian yang dilakukan Rosdiana WD pada tahun 2015 namun pada anak berusia 7-8 tahun menunjukkan hasil bahwa anak dengan kategori kurus memiliki status karies sedang terbanyak, dibandingkan dengan anak ketegori normal dan gemuk. Anak dengan kategori kurus memiliki karies sedang terbanyak dikarenakan perkembangan kelenjar saliva mengalami atrofi sehingga menyebabkan aliran saliva menurun dan mengurangi buffer saliva. ${ }^{18}$

Hubungan berat badan dan kerusakan gigi menjadi isu yang kontraversi di berbagai negara. Asupan makanan yang kaya karbohidrat merupakan salah satu faktor resiko terjadinya kelebihan berat badan, obesitas dan karies. ${ }^{17}$ Prevalensi karies, kelebihan berat badan dan obesitas menjadi salah satu masalah kesehatan di berbagai negara dan hal tersebut mempunyai etiologi yang multifaktorial. ${ }^{19}$

Body mass index (BMI) atau indeks masa tubuh merupakan alat yang sederhana untuk menilai status gizi khususnya yang berkaitan dengan kekurangan dan kelebihan berat badan. ${ }^{11}$ Body mass index (BMI) atau indeks massa tubuh dihitung berdasarkan rumus berat badan dalam kilogram $(\mathrm{kg})$ dibagi dengan tinggi badan dalam meter yang dikuadratkan $\left(\mathrm{m}^{2}\right)$. BMI digunakan secara luas di seluruh dunia karena mudah, murah dan praktis untuk digunakan. ${ }^{20}$

Berdasarkan data dari Dinas Kesehatan Kota Padang, di Puskesmas Rawang pada data kunjungan sepuluh penyakit gigi terbanyak, karies memiliki jumlah kunjungan 1096 pada bulan JanuariOktober 2015. ${ }^{21}$ Program penyuluhan tentang kesehatan gigi dan mulut telah dilakukan pada semua PAUD di wilayah kerja Puskesmas Rawang dan tidak ada dilakukan pemeriksaan indeks karies. Berdasarkan apa yang telah diuraikan diatas, peneliti merasa tertarik untuk melakukan penelitian apakah 
ada hubungan antara body mass index (BMI) dengan status karies anak usia prasekolah di wilayah kerja Puskesmas Rawang Kecamatan Padang Selatan. Penelitian dilakukan pada anak dengan usia 36 sampai 72 bulan karena gigi sulung akan tumbuh lengkap sejumlah 20 buah pada usia 36 bulan. ${ }^{22}$

\section{METODE}

Desain penelitian yang digunakan adalah cross sectional. Suatu bentuk studi observasional (noneksperimental). Penelitian ini dilakukan di TK Barunawati, KB (kelompok bermain) Sayang Mama, KB Cendana, KB Ashhabul Kahfi, TK Ikal Iqrak Perum Bulog, TK dan KB Aisyiyah yang berada di wilayah kerja Puskesmas Rawang Kecamatan Padang Selatan mulai dari bulan November 2015 sampai Maret 2016. Sampel dipilih sesuai kriteria inklusi yang berjumlah 72 orang. Kegiatan Penelitian ini terdiri atas pengukuran berat badan dan tinggi badan dengan menggunakan alat timbangan berat badan serta alat pengukur tinggi badan untuk mendapatkan status BMI kemudaian pemeriksaan gigi untuk mendapatkan indeks def-t pada anak. Data yang diperoleh dianalisis menggunakan uji Kruskal-Wallis untuk membandingkan antara BMI (underweight, normal weight, dan obesitas) dengan status karies, dengan derajat kepercayaan 95\% dan dikatakan bermakna apabila $p<0,05$. Analisis data dilanjutkan dengan analisis post-hoc untuk mengetahui kelompok mana yang bermakna yaitu dengan uji Mann Whitney.

\section{HASIL DAN PEMBAHASAN}

Penelitian ini dilakukan pada sampel penelitian yang memiliki umur berkisar $3-6$ tahun. Analisis Univariat dilakukan untuk melihat distribusi Body Mass Index dan Indeks def-t pada sampel.

Tabel 1. Distribusi BMI

\begin{tabular}{ccc}
\hline Variabel & Jumlah & Persentase \\
\hline Underweight & 28 & $38,9 \%$ \\
Normal & 40 & $55,6 \%$ \\
Overweight & 0 & $0 \%$ \\
Obesitas & 4 & $5,6 \%$ \\
\hline Total & 72 & $100 \%$ \\
\hline
\end{tabular}

Berdasarkan tabel diatas, dapat dilihat bahwa murid dengan kategori normal weight memiliki jumlah terbanyak yaitu 40 orang $(55,6 \%)$.

Tabel 2. Distribusi def-t

\begin{tabular}{cc}
\hline & Def-t \\
\hline Median & 4,00 \\
Modus & 0
\end{tabular}


Fakultas Kedokteran Gigi Universitas Andalas

Jalan Perintis Kemerdekaan No. 77 Padang, Sumatera Barat

Web: adj.fkg.unand.ac.id Email: adj@dent.unand.ac.id

$\begin{array}{cc}\text { Standar Deviasi } & 3,89 \\ \text { Nilai Minimum } & 0 \\ \text { Nilai Maksimum } & 16\end{array}$

Berdasarkan tabel diatas, dapat dilihat bahwa indeks deft siswa dari 6 PAUD tersebut adalah 4,00. Nilai Minimum dari indeks def-t adalah 0 , serta nilai maksimum indeks def-t adalah 16 . Sebelum melakukan uji bivariat dilakukan uji normalitas data terlebih dahulu. Hasil uji normalitas data memperlihatkan nilai $\mathrm{p}<0,05$ dan disimpulkan bahwa data tidak terdistribusi dengan normal. Hasil uji normalitas data untuk BMI dan def-t adalah sebagai berikut:

Tabel 3. Uji Normalitas Kolmogorov Smirnov

\begin{tabular}{cc}
\hline & Signifikan $(\mathbf{p})$ \\
\hline BMI & 0,000 \\
Def-t & 0,005 \\
\hline
\end{tabular}

Pada penelitian ini, untuk melihat hubungan dari variabel independen yaitu BMI (underweight, normal weight dan obesitas) dengan variabel dependen yaitu status karies, maka dilakukan dengan uji Kruskal Wallis dengan tingkat kemaknaan $(p<0,05)$.

Tabel 4. Hasil Uji Kruskal-Wallis

\begin{tabular}{cccc}
\hline Kategori & Rata-rata def-t & Standar Deviasi & $\mathbf{P}$ \\
\hline Underweight & 5,89 & 4,52 & \\
Normal weight & 3,92 & 3,17 & 0,035 \\
Obesitas & 1,00 & 2,00 & \\
\hline
\end{tabular}

Hasil dari uji Kruskal Wallis untuk BMI (underweight, normal, obesitas) dengan def-t pada tabel 6 adalah nilai $p=0,035(p<0,05)$ sehingga diketahui terdapat perbedaan bermakna.

Tabel 5. Hasil Uji Mann- Whitney

\begin{tabular}{cc}
\hline Kategori & $\mathbf{P}$ \\
\hline Underweight dengan normal & 0,102 \\
Normal weight dengan obesitas & $0,024^{*}$ \\
Normal dengan Obesitas & 0,075 \\
\hline
\end{tabular}

Keterangan: $p<0.05$ 
Berdasarkan tabel 5, untuk melihat hubungan antara indeks def-t pada masing- masing kategori maka dilakukan uji Mann-Whitney. Hasil dari uji Mann- Whitney bahwa terlihat perbedaan yang bermakna $(p<0,05)$ pada hasil uji Underweight dengan obesitas. Hasil ini memperlihatkan adanya perbedaan indeks def-t yang bermakna pada kelompok underweight dengan obesitas. Kelompok underweight dengan normal weight dan normal weight dengan obesitas tidak memperlihatkan perbedaan yang bermakna $(p>0,05)$. Hal ini memperlihatkan tidak terdapat perbedaan indeks def-t yang bermakna pada kelompok underweight dengan normal weight dan normal weight dengan obesitsas.

Hasil penelitian ini menunjukkan status karies ditemukan tinggi diantara anak-anak dengan kategori BMI underweight. Hasil indeks def-t pada anak dengan underweight adalah 5,89 yang termasuk dalam kategori tinggi berdasarkan kategori perhitungan def-t menurut WHO. Hasil penelitian ini juga menunjukkan bahwa ada perbedaan def-t yang bermakna pada hasil uji perbandingan pada kelompok underweight dengan obesitas (tabel 5.7). Hubungan antara kekurangan berat badan dengan karies disebabkan oleh asupan gizi yang tidak memadai. Gizi yang buruk dapat meningkatkan karies karena berubahnya komposisi saliva dan gangguan sekresi saliva. ${ }^{23}$ Hipofungsi dari kelenjar saliva telah dilaporkan bisa disebabkan oleh malnutrisi. ${ }^{24}$ Saliva mampu meremineralisasikan karies yang masih dini karena banyak sekali mengandung ion kalsium dan fosfat. ${ }^{25}$

Hal ini berkaitan dengan penelitian yang dilakukan oleh Rosdiana WD tahun 2015 di Jawa Tengah namun pada masa periode gigi bercampur, menunjukkan anak dengan kategori kurus memiliki status karies sedang terbanyak. Menurut Rosdiana WD anak dengan kategori kurus memiliki status karies sedang terbanyak dikarenkan perkembangan kelenjar saliva mengalami atrofi sehingga menyebabkan aliran saliva menurun dan mengurangi buffer saliva. ${ }^{18}$

Menurut Atzmaryanni E tahun 2013 indeks karies rendah pada anak obesitas dibandingkan dengan anak normal, hal tersebut dipengaruhi oleh peningkatan kadar leptin. Leptin merupakan nonglycodylatad peptide yang dihasilkan oleh gen obese dan bekerja di resptor neural pada susunan saraf pusat, yaitu di hipotalamus berat badan. Kadar leptin manusia sangat dipengaruhi oleh berat badan, dan jumlah lemak dalam tubuh, produksi leptin pada orang obesitas lebih banyak 2 kali lipat per gram, karena sel lemak pada obesitas membesar 2-4 kali daripada orang normal. Leptin selain ditemukan pada serum dan plasma, bisa juga didapatkan di rongga mulut, yaitu saliva dan cairan krevikular gingiva. Leptin di saliva dapat menginduksi produksi sitokin yang dapat mempengaruhi sistem imun dalam rongga mulut. ${ }^{26}$ Penelitian yang dilakukan oleh Mohammadi di Iran tahun 2012 pada anak usia 6 tahun menyebutkan juga bahwa BMI mempengaruhi karies gigi. Namun menurut Mohammadi pengaruh gizi terhadap karies memiliki banyak faktor yang mempengaruhi, seperti pendidikan, pengetahuan, sosial ekonomi dan pola hidup. ${ }^{27}$

\section{SIMPULAN}

Berdasarkan penelitian yang telah dilakukan dapat disimpulkan danya hubungan yang bermakna antara BMI dengan status karies anak usia prasekolah di wilayah kerja Puskesmas Rawang Kecamatan Padang Selatan Kota Padang, dimana status karies tinggi pada anak dengan kategori underweight. 


\section{KEPUSTAKAAN}

1. Popoola BO, Denloye OO, Iyun, OI. Influence of Parental Socioeconomic Status on Caries Prevalence Among Children Seen at The University College Hospital, Ibadan. Annals of Ibadan Postgraduate Medicine. 2014 Apr 14; 11(2): 81-86.

2. Garbin CA, Soares GB, Docusse FR, Garbin AJ, Arcieri RM. Oral Health Education in School: Parents' Attitudes and Prevalence of Caries in Children. Revista de Odontologia da UNESP. 2015 Oct;44(5): 285-291.

3. Arderius A, Veiga N, Godinho, Ribeoro C. The Influence of Parents' Educational Level in Children's Oral Health Behavior. Public Health Research. 2015;5(1): 28-31.

4. Borges HC, Garbin CA, Saliba O, Saliba NA, Moimaz SA. Socio-behavioral Factors Influence Prevalence and Severity of Dental Caries in Children with Primary Dentition. Brazilian oral research. 2012 Dec;26(6): 564- 570.

5. World Health Organization. Oral Health: Oral Diseases and Condition. 2012. http://www.who.int/mediacentre/factsheets/fs3 18/en/. (Diakses 20 Desember 2015).

6. Dye BA, Thornton-Evans G, Li X, Lafolla TJ. Dental Caries and Sealant Prevalence in Children and Adolescents in The United States, 2011-2012. US Department of Health and Human Services, Centers for Disease Control and Prevention, National Center for Health Statistics; 2015 Mar.

7. Syed Shahbano, Nisar N, Khan N, Dawani N, Mubeen N, Mehreen Z. Prevalence and Factors Leading to Early Childhood Caries Among Children (71 months of age or younger) in Karachi, Pakistan. Journal of Dentistry and Oral Hygiene, 2015 Sep;7(9): 153-159.

8. World Health Organiazation. Global Strategy on Diet, Physical Activity and Health: Dental Diseases and Oral health. 2003 . (Diakses 20 Desember 2015) Available from: http://www.who.int/oral_health/publications/e n/orh_fact_sheet.pdf.

9. Snehal P, Srinivasan SR, Khatri S. Prevalence of Untreated Dental Caries Among the Preschool Children of Western Maharashtra. Journal of Dentistry and Oral Hygiene, 2015;7(11): 175-178.

10. Qiu RM, Lo EC, Zhi QH, Zhou Y, Tao Y, Lin HC. Factors Related to Children's Caries: a Structural Equation Modeling Approach. BMC public health. 2014 Oct;14(1): 1071.

11. Soetjiningsih Ranuh, IG.N Gde . Tumbuh Kembang Anak. Edisi 2. Jakarta: EGC; 2012.

12. Winda SU, Gunawan P, Wicaksono DA. Gambaran Karies Rampan pada Siswa Pendidikan Anak Usia Dini di Desa Pineleng II Indah. e-GIGI. 2015;3(1).

13. Penelitian, Badan. Riset kesehatan dasar. Departemen Kesehatan Republik Indonesia, 2013.

14. Susi S, Bachtiar H, Azmi U. Hubungan Status Sosial Ekonomi Orang Tua dengan Karies pada Gigi Sulung Anak Umur 4 dan 5 Tahun. Majalah Kedokteran Andalas. 2015;36(1).

15. Edalat A, Abbaszadeh M, Eesvandi M, Heidari A. The relationship of Severe Early Childhood Caries and Body Mass Index in a Group of 3- to 6-Year-Old Children in Shiraz. Journal of Dentistry. 2014;15(2): 68. 
Fakultas Kedokteran Gigi Universitas Andalas

Jalan Perintis Kemerdekaan No. 77 Padang, Sumatera Barat

Web: adj.fkg.unand.ac.id Email: adj@dent.unand.ac.id

16. Chopra A, Rao NC, Gupta N, Vashisth S, Lakhanpal M. Influence of Behavioral Determinants on Deviation of Body Mass Index Among 12-15 Years Old School Children of Panchkula. Epidemiology and health. 2014;36.

17. Bafti LS, Hashemipour MA, Poureslami H, Hoseinian Z. Relationship Between Body Mass Index and Tooth Decay in a Population of 3-6-Year-Old Children in Iran. International journal of dentistry, 2015, 2015.

18. Rosdiana WD. Pengaruh Frekuensi Konsumsi Makanan Kariogenik Dan Status Gizi Terhadap Status Karies Siswa Sd Negeri Ngadirejo I Usia 7-8 Tahun, Kecamatan Kartasura, Kabupaten Sukoharjo. Diss. Universitas Muhammadiyah Surakarta. 2015.

19. Chukwumah NM, Azado CC, Adeghe HA, Enabulele JE. Relating Dental Caries Experience with Body Mass Index Among Nigerian Primary School Children: A Cross- Sectional Survey. Journal of Education and Ethics in Dentistry. 2012; 2(1): 28.

20. National Obesity Observatory. Body Mass Index as A Measure of Obesity. 2009. (diakses 20 Desember 2015) Available from: http://www.noo.org.uk/uploads/doc789_40_no o_BMI.pdf.

21. Laporan Pelayanan Program Gigi dan Mulut Puskesmas Kota Padang. Dinas Kesehatan Kota Padang. Padang. 2015.

22. Maulani Chaerita. Enterprise, Jubilee. Kiat Merawat Gigi Anak. Jakarta: Elex Media Komputindo; 2005.

23. Mishu MP, Hobdell M, Khan MH, Hubbard RM, Sabbah W. Relationship Between Untreated Dental Caries and Weight and Height of 6-to 12-Year-Old Primary School Children in Bangladesh. International journal of dentistry. 2013 Apr; 2013.

24. Wong David T. Salivary Diagnostics. USA: Willey-Blackwell; 2008.

25. Kidd Edwina A. M, Bechal, J.S. Dasar - Dasar Karies Penyakit dan Penanggulangan. Jakarta: EGC; 2012.

26. Atzmaryanni E, Rizal MF. Kadar Leptin Saliva dan Kejadian Karies Gigi Anak Obesitas (Salivary Leptin Levels and Caries Incidence in Obese Children). Dental Journal (Majalah Kedokteran Gigi). 2013;46(3):158- 161.

27. Mohammadi TM, Hossienien Z, Bakhteyar M. The Association of Body Mass Index with Dental Caries in an Iranian Sample of Children. Journal of Oral Health and Oral Epidemiology. 2012;1(1): 29-35. 